\title{
'Race' and inequality in postcolonial urban settings \\ Examples from Peru, Jamaica, and Indonesia ${ }^{1}$
}

\author{
PETER J.M. NAS, RIVKE JAFFE, and LINE ALGOED
}

\begin{abstract}
ABSTR ACT
In this essay we present three case studies of Peru, Jamaica and Indonesia to illustrate the use of the concept of race in daily life in relation to labour, popular culture and beauty respectively. These cases demonstrate how the use of the concept of race changes in the transition from a colonial into a postcolonial setting, depending on the role of the state and nation building. In Peru, we see a clear continuation of racialized thinking; thinking and speaking in terms of 'race' is still the norm. In Jamaica we find a process of inversion: the concept of race is maintained as a frame of societal analysis, but blackness is revalidated and has become a prerequisite for national and cultural belonging. In Indonesia racialized categorizations have disappeared almost completely as 'race' has become subjected to the development rhetoric, which just allows limited space for ethnic manifestations. However, discrimination on other rhetorical basis, such as non-citizenship, remains.

KEYWORDS

Race, beauty, skin, city, servants, songs.
\end{abstract}

Human identifications and behaviour tend to articulate a combination of the individual and the social. Being an individual requires diversity and difference in relation to others, while being social requires conformity and comprehension. The interaction of these two aspects constitutes a fundamental drive for social distinction, resulting in individual and social identities. Extreme and moderate forms of social distinction can be seen as fundamental forces resulting in a great diversity of historically produced configurations. Such distinctions are made along a variety of lines, a prominent distinction being 'race'. The twentieth century saw scientists turn to the concept of ethnicity, which refers not only to 'racial' but to every human characteristic applied in constructing social division or similarity. Regarding patterns of social distinction in general, two broad types of societal configurations can

$1 \quad$ This article is a side product of fieldwork in Indonesia by Peter J.M. Nas (Leiden University), in Jamaica by Rivke Jaffe (University of the West Indies, Mona) and in Peru by Line Algoed (Project Coordinator for INTA, the International Urban Development Association, The Hague). About the authors see after Bibliography. 
be distinguished. The first type of society considers individuals and social units to be of intrinsically unequal value, though equality can be found within the constituting units. The second type of society considers all individuals and social units to be of equal value, while differences are accommodated within this framework of equality. These two value systems produce varied societies. ${ }^{2}$

The first type is rooted in the idea that human beings and their social systems and cultures are fundamentally unequal. This inequality can be constructed on the basis of differences in religion, economy, culture, skin colour and physiognomy ('race') or other characteristics. Within the different constituting parts some basic unity is assumed and in extreme cases even advanced by the eradication of diverging, competing or threatening entities, as was the case with Nazism. Many colonial societies were founded on the belief of such inherent, unalterable differences. Change of such systems may occur through gradual value erosion, for instance following external influences, or by fundamental revolution.

The second type is based on the premise of universal civil rights. Within this setting differences are accommodated, including those based on 'biological' markers of skin colour, gender and age and those based on 'cultural' variety in class, regional and cultural background, and religion. Such differences may have a powerful impact on job opportunities or access to services such as housing and education. Some societies of this type will attempt to counteract such decision-making through concrete social and legal affirmative action.

These two types of societal configurations have been elaborated concretely in different historical settings and combinations, for instance feudal, communist, slavery and democratic systems. The last century, however, was characterized by a significant shift towards societies based on the premise of equality. In this short note on 'race' and inequality, we will focus on such shifts by studying the transformation of the concept of race in three postcolonial societies: Peru, Jamaica and Indonesia. The change in inequality of these three countries from the colonial to the postcolonial era entailed a shift from the first to the second type of society. We study ambivalent attitudes towards 'race' - constructed on the basis of physiognomy and particularly skin colour - at national and individual levels, in the context of a shift from a colonial to a postcolonial state. In all three countries the concept of 'race' played a powerful role during the colonial era, legitimizing imperial hegemony and inequity. The three postcolonial societies discussed here were chosen as examples because they developed along notably different paths. We illustrate these different paths using examples that demonstrate postcolonial conceptions of 'race' and clarify how the postcolonial nations have dealt with racial inequity. The examples used are the behaviour towards indigenous female domestic workers in Peru; songs related to skin colour in Jamaica; and ideas on female beauty in Indonesia. We choose these three cases - labour, popular culture and beauty

This distinction was also brought forward by André Dumont with respect to India and the West. 
- to highlight the differences in national contexts because they represent, for each country, a critical site for the negotiation of difference.

\section{PERU}

Numerous sources concur that even now true decolonization has not yet occurred in Peru. European culture is still much admired whereas many consider traditional, indigenous cultures 'barbarian'. Peruvians of European descent still treat those of indigenous or African descent as fundamentally different and inferior individuals, almost as if decolonization never had taken place.

At the time of the Spanish conquest, the indigenous population was deemed of scarce value and in need of Spanish guidance so they could be moulded into the right shape. Serving the Spaniards was considered the indigenous population's natural fate (Portocarrero 1993: 76). In order to 'thank' the Spaniards for the benefits they were bestowing by providing them with civilization, indigenous people were forced to work in all kinds of humiliating occupations. The criollos, former colonizers who had become the local elite, fought for independence in the nineteenth century. While independence was achieved through a political revolution, it was never accompanied by a social revolution. The criollo elite felt itself to be closely related to theSpaniards, rather than to the indigenous people, who constituted the majority of the country. Consequently, the nation-state that resulted from this was based from the start on the exclusion of the majority. Colonial racism was adopted as one of the fundamental pillars upon which the criollos built their own domination (Manrique 2002: 335). The establishment of an integrated nation of 'Peruvians' seems to have failed. The 'Peruvian' society incorporated only small groups of criollos, while the indigenous populations never actually gained full independence (Boesten 2004: 52). Republican Peru thus reproduced an exclusionary hierarchy based on the racial discrimination that was characteristic for the colonial age (Boesten 2004: 54).

Peruvians sometimes promote mestizaje, intermarriage between criollos and the indigenous population, as an avenue to equality. The fact that the mestizaje occurs increasingly does not involve an erasure of the problems of racial discrimination. The ideology of mestizaje, which states that everybody in Peru is equal, is actually a cover-up of reality, and entails forgetting that domination and violence also take part in sexual relations. Mestizaje did, of course, occur; the massive migration flows from the mountainside to the cities of the last six decades have produced a major interrelation of cultures in Peru, but nevertheless racism is still rampant (Manrique 2002: 335). In fact, the children born from mixed marriages are only considered as a positive result if this 'whitens' the Peruvian population. This can be seen as a background to the stimulation of European immigration in the last centuries.

Ever since the European conquest, the Amerindian population has been assigned the least popular tasks, a situation that led to the belief that indigenous people performed these tasks not as a result of the colonial conquest but rather due to their natural servility and inferiority (Barrig 2001: 34). Not only the criollos but even the native population internalized this belief 
in such a way that it became a sort of social common-sense, a common sense that is still prevalent in contemporary Peru. The limited humanity attributed to Amerindians has inhibited their civil rights and privileges.

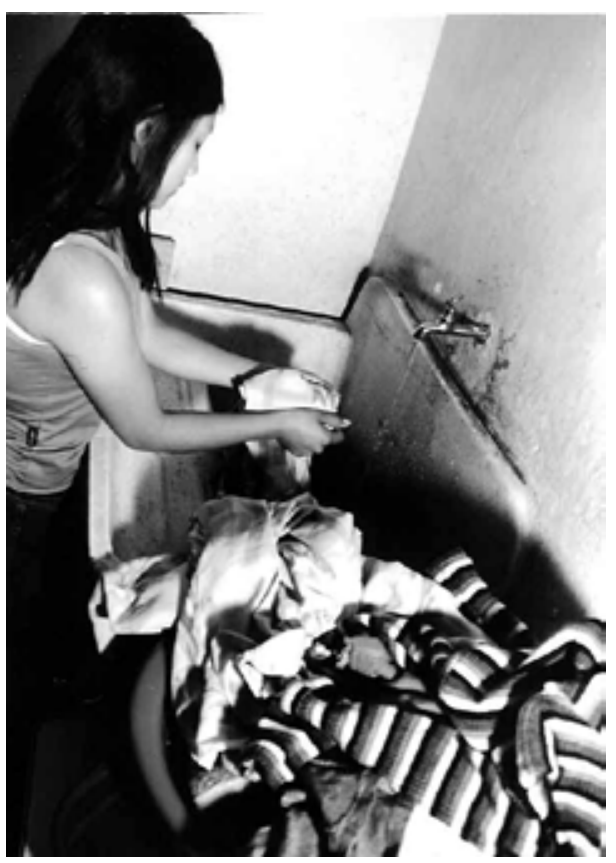

Figure 1: Working in the household, Lima. (Photograph: Arturo Quispe 2004).

The Peruvian system of domestic servants in present-day Peru reproduces relationships similar to those in the colonial period. Employers believe they are dealing with a fundamentally different and inferior type of human being and they feel the urge to socialize rural indigenous women in their own urban, 'white' atmosphere. Employers attempt to change clothing and daily patterns of language use and social interactions of the female migrants, trying to incorporate the indigenous women in 'national' spaces. Previous to their acquaintance with the urban areas' 'superior' culture, these women were regarded as 'non-national' individuals waiting for their place in nationhood (Radcliffe 1999: 86).

The ignorance attributed to indigenous women is not so much a product of their illiteracy. Rather, it is seen as an inherent primitive nature, compelling employers to take such a girl under tutelage and treat her in an infantilized way (Barrig 2001: 35). The difference between the servant and the female patrona goes beyond the different levels of education. The acceptance of inferiority as an inherent feature of the indigenous women becomes installed in Peru's generalized social knowledge, and entitles employers to take over their servants' lives. For many young women, 'socialization' was in fact a motivation for migrating and domestic work, which they hoped would be a bridge to another, better life. Nevertheless most women stick to these jobs, since other possibilities are unavailable. The socialization tactic employed by the patronas is to try to make the women stay with them as employees, and then always inside the house. The urban world outside is depicted as full of danger, in an attempt to prevent friendships or love relations. This allows the employer to abuse her servant, making her work up to sixteen hours a day and leaving no space for the development of self-esteem.

Common terms of reference and address for domestic workers are muchacha or chica (girl). These are not allusions to age, but rather to social position: they are seen as permanent minors (Barrig 2001: 33). Upper-class women see themselves as social, symbolic mothers to the working-class women, designated as 'daughters' or 'children' in need of moral guidance. 
The common use of the word hija, daughter, by the señoras creates a fictitious kinship that conceals the economic and racialized hierarchy constructed between the two parties. The cosmetic nature of this invocation of kinship is evident in the general disregard for the domestic workers' wellbeing. The representations of domestic workers as 'girls' have manipulated familial and national vocabulary to embed the workers into a position of dependence and subordination. As a result, they do not merit the same rights and privileges as other citizens (Stephenson 1999: 28). If something happens to them, for instance should they be raped by an employer, no one seems to care; this is accepted as part of the reality.

The relationship between domestic servants and their employers is one marked by paternalism, dependence, limitation of mobility, violence and racism; similar to the relationship between the conquerors and the Indians. The women who work as domestic servants are supposed to be grateful for everything given to them by their employers, and are expected to accept all the hardships involved. The abuse of domestic servants is an example of the consequences of the racialized perceptions of lower-class Indian women marking Peruvian society.

State actions against the situation of domestic servants, and against racism in general, have proved to be insufficient. Although domestic household workers' labour conditions are regulated, this is actually just another proof of their inferior status. They receive half the regular vacation time and have no fixed minimum wage; in addition this regulation is not enforced. The state does not challenge the discrimination that harms millions of its citizens, denying the majority of the population access to quality education, decent medical care and the opportunity to find high-standard jobs. This situation condemns a large part of the population to live in serious poverty; few efforts are made to promote the multicultural character of the country, which would be a way of stimulating unity between different social groups and an attempt to eradicate discrimination. The current president Alejandro Toledo and his European wife Elian Karp have repeatedly said they want to work for Peruvian multiculturalism, but so far this has only happened in a symbolic way. Both use indigenous symbols to represent the country's plural character, to enable the imagining of a nation state united in collective belonging. Yet in this instance, the use of symbols indicates that this unity needs to be emphasized, exactly 'because it does not exist' (Boesten 2004: 56).

\section{JAMAICA}

Jamaica is the largest of the Anglophone Caribbean islands, colonized in 1655 by the British, who grew wealthy developing sugarcane plantations, making extensive use of African slave labor. The white elite was always very small; Europeans never represented more than a few percent of the population. A so-called plantation society developed, characterized by economic dependency and 'an abiding Eurocentrism which puts everything European in a place of eminence and things of ... African origin in a lesser place' (Nettleford 1978: 3). In 1807, Britain declared slave trade illegal, but slavery itself was 
not completely abolished in the British colonies till 1 August 1838. Most emancipated slaves left the plantations as soon as possible, which resulted in a large labor shortage for the plantation owners, mitigated somewhat by the advent of indentured servants from India and China. In 1962, Jamaica was granted independence from Britain. These three institutions - slavery, the plantation system and colonialism - are the historical context from which the social, cultural, political and economic patterns of modern Jamaica can be said to derive (compare Randall 2003).

Obviously, in a country with a history of slavery and institutionalized racism, 'race' and colour are issues. ${ }^{3}$ The majority of Jamaicans are of African descent, and attitudes towards 'whiteness', 'brownness' and 'blackness' at the individual level still reflect the vestiges of colonial ideologies: a tendency to see 'brownness' or 'whiteness' as the (beauty) ideal (Johnson 2004: 63). Significant numbers of women, as well as smaller numbers of men, use bleaching creams to whiten their skins, and straightened hair is a very common sight. 'Caucasian' features - a light skin colour, 'good' hair, 'thin' lips, a 'straight' nose - are perceived as facilitating social and economic success, and in this bleaching may be a rational strategy (Shepherd 2000: 54-55; Charles 2003). Recent changes notwithstanding, historically there has been a strong correlation between class and colour, with business and politics being dominated by lighter skinned Jamaicans, including ethnic groups of Middle Eastern, Asian and Jewish descent. In addition, it seems likely that the tremendous influence of US mainstream culture through cable TV, movies, and so on perpetuates this white/brown bias. Incessant images of a world in which white people are rich and happy and black people are often represented with negative stereotypes, may sustain prejudices against darker skin resulting in feelings of inferiority or lack of self worth. Rather than the bipolar racial categorization found in the US, Jamaica has a more subtle system of 'colourism' in which brownings are rated higher than blacks. A dark-skinned friend of one of the authors related how she used to be taunted in school by browner children, who would call her black-and-shine and tell her to run get a scouring brush and scrub off the black. Female beauty ideals in particular are characterized by the image of the browning (Kempadoo 2004: 80-81; Mohammed 2000). The valorization of light skin and the conception of female desirability as defined in terms of colour are reflected in the following song by Buju Banton, Love mi browning:

Mi love mi car

Mi love mi bike

Mi love mi money and ting

But most of all

Mi love mi browning
I love my car

I love my motorcycle

I love my money and things

But most of all

I love my brown skinned woman

On the other hand, 'blackness' has strong positive associations as well.

$3 \quad$ As Walvin (1996: 182) remarks, "the racist legacy of black slavery was to prove durable and resistant long after slavery itself had faded from Western thought and memory". For more exhaustive discussions of race, colour and class in Jamaica see Austin (1998); Baronov and Yelvington (2003); Jaffe (2006). 
In Jamaica black nationalism and the politics of race have been employed strategically towards the forging of national unity, based implicitly on the premise of ethnic homogeneity (Afro-Jamaicans as insiders) and a common ethnically distinct 'enemy' or 'oppressor' (white European and American outsiders). Especially in recent decades, the government has leaned towards 'implicit invocations of racialized frameworks for belonging and ownership' (Thomas 2002: 39). Immediately after independence, 'racialized belonging' was subsumed under Creole nationalism, evident in the national motto 'Out of many, one people'. This sentiment is apparent in the following lyrics from the Israel Vibration song Babylon by Bus.

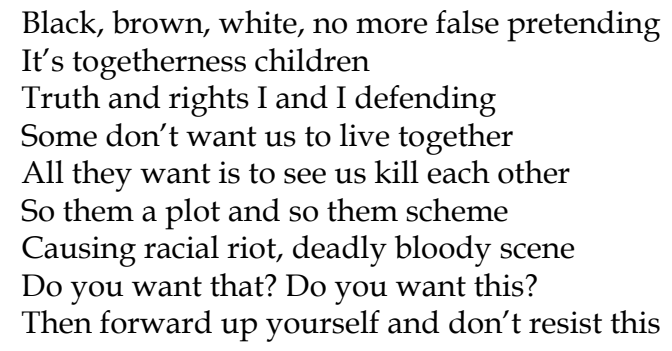

Similar to the Peruvian mestizaje, the Creole ideology served as a legitimizing framework to the light-skinned middle strata who dominated postindependence politics. However in the decades following Independence, black cultural nationalism took precedence and the 'we-group' is now to a certain extent constructed on the basis of 'blackness'. ${ }^{4}$ This was evident in a small way at a dancehall one of the authors went to in Gordon Town, a village just outside Kingston. Around 4 a.m. the police arrived to 'lock off the dance', put an end to the noise by shutting down the sound system. One of the DJs protested this by appealing repeatedly to the policemen's colour: "All a wi here black people [...] police black man like wi!" ${ }^{5}$ Unfortunately, they locked off the dance all the same. The idea of a black nation and the revalorization of blackness are evident in the lyrics to Sizzla's Black Woman and Child.

The Black nation, I love it

From di day mi born mi did know seh

Mi colour a di first, I nuh last

So how yu expect I fi duh certain things

Black woman and child

For you I really have so much love
The Black nation, I love it

From the day I was born I knew that

My colour is the first, I am not last

So how do you expect me to do certain things Black woman and child

For you I really have so much love

The rejection of 'white man tradition' is emphasized in Beenie Man's Stop Live Inna Di Past, yet he continues to associate black with ugly.

$4 \quad$ In addition, as Clarke (1996: 183) notes, "low-status black culture has been not only a national unifying focus for all (or almost all) sections of society, but also a vehicle for projecting a Jamaican black identity onto the international stage".

5 All of us here are black people [...] you, the police are black men just like us. 
What I cyaan understand

Why some man ah revere white man tradition

Talk bout dem a Cowboy and Indian

Like dem no respect dem complexion

Mi black and mi ugly

Africa me come from

One day yu got to

Return to dat land

Selassie I me praise
What I cannot understand is

Why some revere the white man's tradition

Talk about how they are Cowboy and Indians

As if they have no respect for their skin colour

I'm black and I'm ugly

I come from Africa

One day you have to

Return to that land

I praise [Haile] Selassie I

One consequence of racializing in-groups and out-groups is the validation of anti-white convictions, which are expressed militantly by certain groups and individuals, including some Rastafarians. ${ }^{6}$

\section{INDONESIA}

In Indonesia the concept of race is not very current nowadays. Yet, during the colonial period this former Dutch colony was a society segregated along racial lines. Ranking from high to low it distinguished between the Dutch; the 'Indos' (the intermediate group descending from Dutch-indigenous interrelations); groups of Chinese and Arabs known as 'Foreign Orientals' (Vreemde Oosterlingen); and the indigenous population. Although strong antiDutch and nationalist feelings surfaced in the late colonial period, anti-Dutch did not come to imply anti-white. Lighter skin was still generally considered a more beautiful shade. The image of beauty prevalent in contemporary Indonesia is influenced by these colonial racial distinctions, in which the white dominant class and its associated physiognomic characteristics were valued. Skin, nose, shape of the eyes and tallness constitute the beauty standard: the whiter the skin, the better; the nose should be less flat; the eyes should not be slanted; and the body should be taller than average. Visiting a beauty parlour in Yogyakarta in August 2005, it became clear that bleaching and whitening figure prominently among skin beauty treatments. All sorts of bleaching creams are offered, including face creams for use in the morning and evening; even body-whitening without side-effects is propagated. Movie and TV stars are often from a mixed or Indo background and feature the beauty characteristics listed above. In women's periodicals, photographers utilize lighting to portray the models, who recommend all sorts of products ranging from kitchen utensils to cell phones, as favourably as possible by suggesting fair skins and straight noses. The colonial idea of beauty has clearly been continued in the postcolonial era until the present. Conversations with all sorts of people suggest that it is widespread and uncontested, although some women conceive whitening as no more than creating a beautiful shining, yellow skin. Some informants point to the fact that, after the fall of President Suharto and the New Order regime, the Chinese population group acquired

\footnotetext{
6 Rastafari is a socio-religious movement that is concerned, among other things, with a revalidation of Africa and blackness, and dismantling the structures of oppression. An important point of reference in Rastafari beliefs is Haile Selassie, the last Emperor of Ethopia, who they consider to be the Black Messiah.
} 
more leeway in Indonesian society, while the often paler Chinese women also became more prominent in the media.

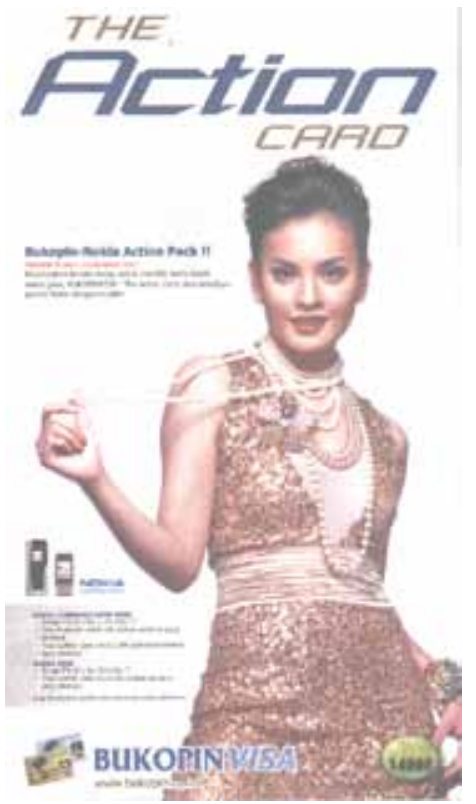

Figure 2: Selling Nokia (Kompas, 10 August 2005, 7).

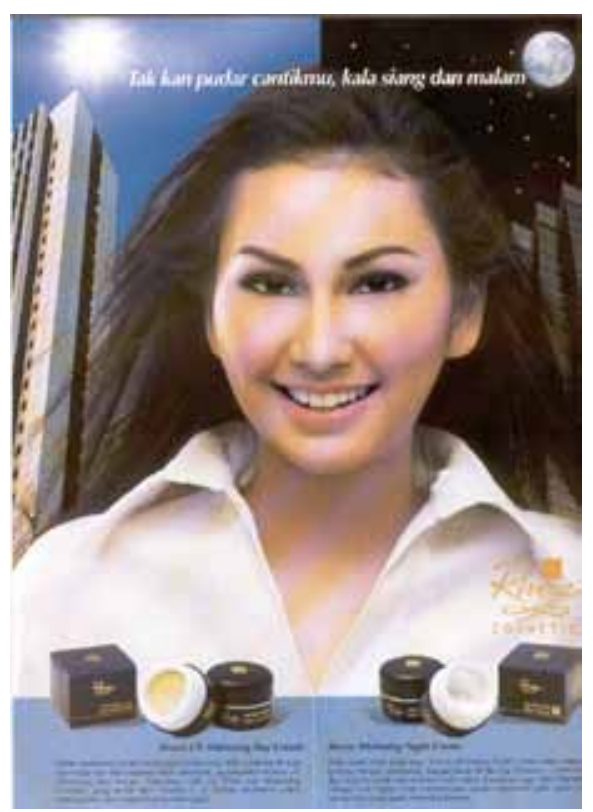

Figure 3: Rivera UV (Kartini 18 August 2005, 50).

In addition to the virtual absence of the use of the concept of race in the postcolonial period, and the continuation of the whitening custom from colonial to postcolonial settings, it is important to acknowledge that Indonesians make distinctions among themselves using the concept of suku or ethnic group. In this view the world is made up by many peoples or bangsa, one of them being the Indonesians. Within Indonesia there are suku such as the Javanese, Sundanese, Indonesian Chinese, Minangkabau and so on. Even very different groups such as the Papoeas and Javanese are just considered to constitute suku differences, and this is at times expressed in forms of discrimination termed sukuisme. The concepts of bangsa and suku could be seen as related to race, but they have such different associations that translation with 'race' would clearly be erroneous. Explaining these conditions should take into account the fact that, in Indonesia in the postcolonial period, nation building received overall priority. Both Presidents Sukarno and Suharto focused on nation building by adopting and promoting one national language and one ideology and by fostering a strong development discourse. Within that nation the people of Indonesia as one unity was stressed, while differences were levelled and separation tendencies eradicated. Only after the 1998 Reformasi did decentralization become more of an option. This means that until that time in the postcolonial period, 'racial' differences were reconfigured as regular ethnic differences, which were allowed and even appreciated as part of folklorization, so that the concept of race was almost completely scratched 
from the vocabulary. Consequently, in this system Indonesian Chinese with the Indonesian nationality (Warga Negara Indonesia) were seen as part of the Indonesian people, but those Chinese with non-Indonesian status (Warga Negara Asing) were considered part of a different people, irrespective of their Indonesian background.

We conclude that the concept of race in postcolonial Indonesia, most probably in reaction to the racially stratified colonial situation, has developed in the context of nation building in such a way that, rhetorically, no differences in race are accepted because of the propagated unity of nation and people. However, certain levels of ethnic difference that do not endanger nation building have been tolerated under the official concept of suku. In accordance with this, during President Suharto's New Order the concept of race surfaced mainly (though not exclusively) in the context of the military facing rebellion and riots. They used the concept of SARA, covering Suku, Agama, Ras, Antargolongan (Ethnic group, Religion, Race and Class) to point at the sources of unrest with which they were confronted. This postcolonial near-denial of the concept of race in the framework of development as a matter of course does not exclude daily and state racism, which is directed against the Chinese minority group in particular. While anti-Chinese measures are evident in for instance the taboo on the use of Chinese characters, names and forms of popular culture, and in physical violence against Chinese, these forms of discrimination are generally couched in terms of 'foreignness' rather than 'race'.

\section{CONCLUSION}

The three cases of Peru, Jamaica and Indonesia demonstrate how the changing use of the concept of race in a postcolonial setting depends on the societal configuration, in particular the role of the state and its project of nation building. In Peru, we see clear continuation of racialized thinking from the colonial into the postcolonial era, despite - or perhaps precisely because of - the country's early decolonization. It is still the norm to think and speak in terms of 'race', a concept that legitimates social relations between the relatively small group of descendants of the former colonists and the indigenous majority. Both at the national and individual level being 'white' means more and better opportunities in society. In Jamaica, 'race' was a principle fundamental to both the colonial era and slavery. The postcolonial period saw a reactive process of inversion - the concept of race is not rejected, but blackness becomes a prerequisite for national and cultural belonging. While bleaching has continued at the individual level, the national level presents black as beautiful in the process of national identity and overcoming the trauma of slavery. In Indonesia the concept of race was firmly embedded in the colonial era, with caste-like distinctions between 'white', 'Indo', 'Foreign Orientals' and 'indigenous' groups. In the postcolonial period, racialized categorizations have disappeared almost completely as 'race' became subjected to nation building and the associated development rhetoric, which allowed very limited space for ethnic manifestations. While sukuisme remains an important source of 
internal differentiation and hierarchy, Indonesia's nationalist development project basically led to the rejection and negation of the concept of 'race' as a differential at the collective level. However, colour and ethnic discrimination still occurs at the individual level. Whitening continues to be a large-scale, accepted phenomenon, though perhaps 'Indo' and more recently Chinese rather than European physiognomies have become the point of reference.

\section{REFERENCES}

Austin, D.J. 1998. "Culture and ideology in the English-speaking Caribbean; A view from Jamaica", in: A. Torres and N. E. Whitten (eds), Blackness in Latin America and the Caribbean; Social dynamics and cultural transformations; Vol. II: Eastern South America and the Caribbean, pp. 436-459. Bloomington: Indiana University Press.

Barrig, M. 2001. El Mundo al Revés; Imágenes de la Mujer Indígena. Buenos Aires: CLASCO.

Baronov, D. and K.A. Yelvington. 2003. "Ethnicity, race, class and nationality", in: R.S. Hillman and T.J. D' Agostino (eds), Understanding the contemporary Caribbean, pp. 209-238. Kingston: Ian Randle.

Boesten, J. 2004. "Negotiating womanhood, reproducing inequalities; Women and social policy in Peru". Ph.D Thesis, University of Amsterdam.

Charles, C.A.D. 2003. "Skin bleaching; Self-hate and black identity in Jamaica", Journal of Black Studies 33: 711-728.

Clarke, C.G. 1996. "Jamaican decolonization and the development of national culture", in: G. Oostindie (ed.), Ethnicity in the Caribbean; Warwick University Caribbean studies, pp. 182-205. London: Macmillan.

Jaffe, R. 2006. “Looking back, forward or up? Urban symbolism and the politics of race in Jamaica's Redemption Song", in: P.J.M. Nas and A. Samuels (eds), Hypercity; The symbolic side of urbanism, pp. 69-84. London: Kegan Paul.

Johnson, T.A. 2004. "The enduring function of caste: colonial and modern Haiti, Jamaica, and Brazil; The economy of race, the social organization of caste, and the formulation of racial societies", Comparative American Studies 2: 61-73.

Kartini 18 august 2005.

Kempadoo, K. 2004. Sexing the Caribbean; Gender, race, and sexual labor. New York: Routledge.

Kompas 10 august 2005.

Manrique, N. 2002. El tiempo del miedo; La violencia política en el Perú 1980-1996. Lima: Fondo Editorial del Congreso del Perú.

Mohammed, P. 2000. “'But most of all mi love me browning'; The emergence in eighteenth and nineteenth-century Jamaica of the Mulatto woman as the desired", Feminist Review 65: 22-48.

Nettleford, R. 1978. Caribbean cultural identity; The case of Jamaica. Los Angeles: CAAS.

Portocarrero, G. 1993. Racismo y mestizaje. Lima: SUR Casa de Estudios del Socialismo. 
Radcliffe, S. 1999. "Race and domestic service", in: J.H. Momsen, Gender, migration and domestic service, pp. 83-97. London: Routledge.

Randall, S. J. 2003. "The historical context", in: R.S. Hillman and T.J. D'Agostino (eds), Understanding the contemporary Caribbean, pp. 51-83. Kingston: Ian Randle.

Shepherd, V.A. 2000. "Image, representation and the Project of Emancipation in the Commonwealth Caribbean", in: K. Hall and D. Benn (eds), Contending with destiny; The Caribbean in the 21st century, pp. 53-79. Kingston: Ian Randle.

Stephenson, M.1999. Gender and modernity in Andean Bolivia. Austin: University of Texas Press.

Thomas, D. A. 2002. "Modern Blackness: 'What We Are and What We Hope to Be'", Small Axe 6: 25-48.

Walvin, J. 1996. Questioning slavery. London and New York: Routledge.

\section{ABOUT AUTHORS}

PETER J.M. NAS is professor at Leiden University and attached to the Department of Languages and Cultures of Southeast Asia and Oceania as well as the Department of Cultural Anthropology and Development Sociology. He teaches urban sociology and anthropology, and has conducted fieldwork in Indonesia. He is editor of numerous publications, amongst others Framing Indonesian realities; Essays in symbolic anthropology in honour of Reimar Schefold (2003, with Gerard Persoon and Rivke Jaffe; Leiden: KITLV Press) and The past in the present; Architecture in Indonesia (2007, with Martien de Vletter; Leiden: KITLV Press and Rotterdam: NAi Press). Peter Nas is executive secretary of the International Union of Anthropological and Ethnological Sciences (IUAES) and chairman of the Association KITLV (Royal Institute of Southeast Asian and Caribbean Studies), Leiden. E-mail: NAS@fsw.leidenuniv.nl; Website: www.leidenuniv.nl/fsw/nas.

RIVKE JAFFE is a lecturer in Sociology and Anthropology at the University of the West Indies, Mona and Jamaica. She completed her PhD on the urban environment in Curaçao and Jamaica at Leiden University, The Netherlands, and has done postdoctoral research for the KITLV (Royal Netherlands Institute of Southeast Asian and Caribbean Studies). Her work currently focuses on the political economy of multiculturalism in Suriname. Her research interests include Caribbean studies, multiculturalism, urban anthropology and sociology, and the urban environment. E-mail: RJaffe@fsw.leidenuniv.nl.

LINE ALGOED is currently working as Project Coordinator for INTA, the International Urban Development Association. Before she has worked as Research Assistant for the Department of Cultural Anthropology and Development Sociology at Leiden University, where she also obtained her MA degree. E-mail: algoedline@hotmail.com. 